\title{
GENEALOGI DAN TRANSFORMASI IDEOLOGI PARTAI BERBASIS ISLAM DI INDONESIA PASCA-ORDE BARU
}

\author{
M. Faishal Aminuddin \\ Universitas Brawijaya Malang, Indonesia \\ E-mail: mfaishal@ub.ac.id \\ Romel Masykuri \\ Universitas Airlangga Surabaya, Indonesia \\ E-mail: romel.masykuri@gmail.com
}

\begin{abstract}
The study of political Islam has not yet paid attention yet to observing the patterns of thought and its transformation in political organization. However, some studies have been conducted and brought analysis with case study in their respective political parties. This article departs from the question of how the genealogy of political Islam is thought and how it is transformed into Islam-based political parties in democratic Indonesia. The analysis unit of this study is Islam-based parties, having main support from Islamic religious organizations and had seat in parliament since the 1999 election. This study reveals an important finding that Islam-based parties had undertaken adjusment while transforming the doctrine of political Islam much more flexible. This is proven through the tracing of consistency between values, platform and the party's program, either in parliament or in public. This study combines historical discursive approach and genealogy as an analytical framework.
\end{abstract}

Keywords: Political thought; Islam-based parties; Middle East.

\section{Pendahuluan}

Pascareformasi 1998, keterbukaan politik yang dibawa oleh demokratisasi menghasilkan kebebasan bagi organisasi dan kekuatan politik untuk muncul dan berkembang. Di antara kekuatan politik yang muncul signifikan adalah organisasi Islam transnasional. Organisasi tersebut berkembang pesat di hampir berbagai kota-kota 
penting dengan membawa konsep politik Islam. ${ }^{1}$ Pergeseran tersebut mempunyai irisan langsung dengan keberadaan organisasi politik lainnya seperti partai politik. Terutama bagi organisasi dan partai politik yang mempunyai titik politik pertemuan ideologi Islam politik.

Di antara berbagai organisasi yang mengusung ideologi politik Islam dan bersifat transnasional adalah Hizbut Tahrir Indonesia (HTI). Organisasi ini menyuarakan purifikasi praktik ajaran Islam dan memiliki cita-cita mengganti konsep demokrasi dengan sistem kbilafah. ${ }^{2}$ Selain itu, beberapa organisasi lainnya yang memberikan pengaruh cukup penting adalah al-Ikhwân al-Muslimûn (IM) dari Mesir, dan kelompok Salafi Wahabi ${ }^{3}$ dari Saudi Arabia. Nilai ideologi, strategi gerakan dan aktor dari ketiga organisasi tersebut sangat mewarnai corak ideologi dan berbagai pergeseran internal dalam partai-partai politik di Indonesia yang berbasis Islam.

Gerakan politik Islam yang sukses dalam melakukan transformasi dari gerakan sosial menjadi gerakan parlementer adalah gerakan Tarbiyah yang digerakkan oleh eksponen aktivis Islam berlatar pendidikan tinggi di Timur Tengah. Pendirian Partai Keadilan (PK) pada tahun 1998 dan menjadi Partai Keadilan Sejahtera (PKS) pada tahun 2003 merupakan bagian dari perjuangan untuk merealisir gagasan besar politik Islam di Indonesia. Para pendiri PKS membuat konsep organisasi PKS hampir mirip dengan IM di Mesir. Mulai dari ideologi politik, konsep dakwah, maupun pemahaman keislamannya. ${ }^{4}$ Salah satu contoh konsep tujuan tarbiyah PKS sebagaimana yang tertera dalam modul Manajemen Tarbiyah Anggota Pemula PKS

\footnotetext{
1 Ahmad Syafi'i Mufid (ed.), Perkembangan Paham Keagamaan Transnasional di Indonesia (Jakarta: Badan Litbang dan Diklat Kementerian Agama RI, 2011).

2 Tujuan dibentuknya Hizbut Tahrir oleh Taqiy al-Dîn al-Nabhânî ialah untuk melanjutkan kembali kehidupan Islam di bawah negara Khilâfah Islâmîyah. Demokrasi di Indonesia oleh aktivis HTI dianggap sistem kufur karena bertentangan dengan sharî́ah Islam. Lihat Taqiyuddin an-Nabhani, Syakbsiyab Islam, Vol. 1 (Jakarta: HTI Press, 2007), 281.

3 Kelompok Salafi adalah kelompok yang mengusung ide dan pemikiran Muhammad b. 'Abd al-Wahhâb di kawasan Arab Saudi yang kemudian populer dengan sebutan Gerakan Wahabi. Di Indonesia, kelompok Salafi masuk melalui para alumni Timur Tengah, terutama yang bersekolah di Universitas-Universitas di Arab Saudi dan Kuwait. Penyebarannya di Indonesia terlihat di di Jakarta, Cileungsi Bogor, Banten, Batam, Bekasi, Tasikmalaya, Nusa Tenggara Barat, Makasar, dan Solo. Mufid (ed.), Perkembangan Paham Keagamaan, xiv.

${ }^{4}$ M. Imdadun Rahmat, Ideologi Politik PKS: Dari Masjid Kampus ke Gedung Parlemen (Yogyakarta: LKiS, 2008), 97.
} 
menyebutkan bahwa tarbiyah diharapkan menghasilkan para peserta yang memiliki kriteria tertentu, di antaranya aqidah yang lurus (sâlim al-aqîdah), ibadah yang benar (sâliḥ al-íbâdah), dan mampu memerangi nafsu (mujâhid li nafsib). ${ }^{5}$ Kebijakan politik PKS juga banyak menyoroti perkembangan politik di Timur Tengah dan mengangkat isu-isu antizionisme dan pro-Palestina. ${ }^{6}$ Sedangkan dalam konteks hubungan perseorangan dengan IM di Mesir misalnya, bisa dilihat dari posisi Hilmi Aminuddin yang sempat sebagai Murâqib 'Âm (pemimpin) IM Cabang Indonesia dan Yusuf Supendi yang menyebut diri sebagai Sekjen IM Maktab Asia Pasifik.?

Selain PKS yang tumbuh dari gerakan sosial dan bertransformasi menjadi organisasi politik parlementer, keberadaan partai-partai berbasis Islam yang mempunyai sejarah panjang di Indonesia juga penting untuk diamati. Di antaranya terdapat Partai Persatuan Pembangunan (PPP) dan Partai Bulan Bintang (PBB) yang selama ini merawat platform ideologi dan basis konstituensinya dari hubungan tradisional dalam kelompok-kelompok organisasi Islam di Indonesia. Sekalipun demikian, pengaruh pemikiran politik dari Timur Tengah cukup mewarnai ditingkatan elite partainya. Partai lain yang menggunakan basis konstituensi organisasi Islam namun menjadikan dasar negara Pancasila sebagai ideologi politik partai seperti Partai Kebangkitan Bangsa (PKB) dan Partai Amanat Nasional (PAN) dan partai-partai kecil lainnya, bisa diidentifikasi membawa perjuangan nilai-nilai keislaman. Gagasan pemikiran dari Ḥasan al-Bannâ, Ali Sya'riati, Muḥammad Husayn Haykal, M. Rashîd Rị̣̂a, Ayatullah Khomeini dan tokoh-tokoh pemikir politik Islam lain dari Timur Tengah cukup mempengaruhi. Identifikasi yang lebih khusus bisa dilihat dari cara pandang partai dan elitenya terhadap konsepsi hubungan agama dan negara.

\footnotetext{
5 Ibid., 243.

${ }^{6}$ Mohammad Riza Widyarsa, Syafiuddin Fadlillah, dkk., "Pengaruh Ideologi Politik Islam di Indonesia Terhadap Partai Politik di Indonesia: Studi Kasus Partai Keadilan Sejahtera", Jurnal al-Azhar Indonesia, Vol. 1, No. 1 (Maret 2011), 28.

7 Indikasi adanya relasi struktural PKS dan al-Ikhwân al-Muslimûn didasarkan kepada surat tertulis yang didapat Majalah Gatra tertanggal 26 September 2010. Surat tersebut ditulis oleh Yusuf Supendi yang pada saat itu menjabat anggota Majelis Syuro PKS kepada pemimpin tertinggi al-Ikhwân al-Muslimûn, Mursyid Am. Dalam surat tersebut Yusuf meminta al-Ikhwân al-Muslimûn ikut terlibat menyelesaikan konflik internal PKS. Sinyal Relasi Struktural PKS-Ikhwan, Majalah Gatra Edisi 24-30 Maret 2011.
} 
Hubungan antara diseminasi pemikiran dengan gerakan politik Islam dari Timur Tengah ke Indonesia menarik untuk dicermati. Artikel ini berangkat dari pertanyaan; Bagaimana genealogi pemikiran politik dari Timur Tengah dan transformasinya dalam organisasi Islam politik di Indonesia? Sejauh mana revitalisasi dan modifikasi pemikiran politik tersebut dilakukan dalam konteks kebutuhan partaipartai Islam dan berbasis ideologi Islam tersebut? Artikel ini melakukan investigasi terhadap pola relasi dan manifestasi dari transformasi gagasan dan pemikiran politik Islam di dalam organisasi politik di Indonesia. Kami membatasi unit analisis terhadap partaipartai politik berbasis Islam yang mempunyai kursi di parlemen dengan argumentasi bahwa derajat aktualisasi ideologi politik bisa dinilai secara langsung terkait dampak dan luasan pengaruh ideologi tersebut dalam kehidupan bernegara. Kertas kerja ini disajikan dengan pembahasan tentang genealogi pemikiran politik Islam di organisasi politik, transformasi pemikiran ke dalam ideologi, platform partai dan manifestasi di dalam kebijakan partai, dan sejauh mana advokasi dilakukan sebagai bagian dari perjuangan politik parlementer.

Studi ini berangkat dari berbagai studi yang dilakukan sebelumnya tentang pemikiran dan gerakan politik Islam di Indonesia. Studi M. Imdadun Rahmat dalam buku Ideologi Politik PKS: Dari Masjid Kampus ke Gedung Parlemen menggunakan pendekatan analisis historis untuk menemukan relasi ideologi antara PKS dan IM. ${ }^{8}$ Dia membahas secara rinci mulai dari sejarah kemunculan PKS, ideologi PKS yang terpengaruh oleh Masyumi dan IM, hingga pandangan PKS terhadap nation state. Studi tersebut menemukan beberapa hal penting. Pertama, eksponen pendiri PKS mempunyai keterkaitan dengan aktivis Tarbiyah yang berkembang mulai tahun 1970-an. Di antara elemenelemannya adalah Dewan Dakwah Islamiyyah Indonesia (DDII), Lembaga Dakwah Kampus (LDK), alumni perguruan tinggi dari Timur Tengah, dan para dai (pendakwah) lulusan pesantren. Kedua, pembangunan nilai ideologi dan organisasi banyak mengadopsi dari IM sebagai rujukan. Di antaranya adalah asas partai, tujuan Tarbiyah, kaderisasi, dan misi partai yang ingin menjadikan kehidupan Indonesia sesuai dengan ajaran Islam. Ketiga, kendatipun berkiblat pada IM, sikap politik PKS bersifat moderat dan menyesuaikan dengan Indonesia yang menganut konsep negara bangsa (nation state). Studi ini banyak menyajikan data hubungan langsung antara PKS dan IM

${ }^{8}$ Rahmat, Ideologi Politik PKS. 
namun belum memberikan gambaran bagaimana hubungan ideologi antara PKS dan IM berdampak terhadap strategi politik PKS di Indonesia dan sejauh mana revitalisasi nilai-nilai yang terkandung dalam IM itu dikembangkan.

Studi lain tentang PKS dilakukan oleh Arief Munandar dalam disertasi "Antara Jamaah dan Partai Politik: Dinamika Habitus Kader Partai PKS dalam Arena Politik Indonesia Pasca Pemilu 2004".? Dalam studi ini, dia menelitei proses kaderisasi PKS dan hubungannya dengan dinamika faksi-faksi dalam internal partai. Beberapa temuannya adalah Pertama, PKS tidak lahir sebagai representasi dari kelas sosial tertentu, melainkan sebuah ideologi atau pemikiran keagamaan. Kedua, PKS mewakili kategori baru yang merupakan varian dari the modern cadre party, yaitu partai kader berbasis gerakan keagamaan (the religious movement-based cadre party). Secara khusus, studi ini memberikan kontribusi teoretik baru dalam melihat perkembangan partai Islam, terutama partai yang proses kaderisasinya bertumpu pada gerakan Tarbiyah, seperti PKS. Sekalipun demikian, kertas kerja ini membutuhkan studi lanjutan untuk menilai dampak dari proses kaderisasi terhadap perjuangan parlementer.

Studi lain tentang partai politik Islam dilakukan oleh Zudi Zetiawan dalam artikel "Dinamika Pergulatan Politik dan Pemikiran Formaliasi Syariah pada Era Reformasi". Dalam studi ini dia berangkat dari usaha formalisasi sharî‘ah ke dalam konstitusi pasca1998 semakin menguat. Hal ini didasari oleh beberapa hal. Pertama, munculnya ormas Islam pendukung formalisasi sharî‘ah, seperti HTI, FPI, Majelis Mujahidin Indonesia. Kedua, berdirinya partai Islam baru, PKS, PKB, PAN, PBB. Ketiga, adanya tuntutan pemberlakukan Piagam Jakarta dalam konstitusi. Keempat, munculnya gerakan penegakan sharî́ah Islam di daerah melalui Peraturan Daerah. Studi tersebut mendapatkan pembanding dari melambatnya usaha-usaha formalisasi sharî́ah karena tidak didukung oleh kekuatan organisasi Islam mayoritas seperti NU dan Muhammadiyah. ${ }^{10}$

Ahmad Fuad Fanani menyoroti perjalanan partai politik Islam pascareformasi yang cenderung mengalami penurunan suara. Dia

9 Arief Mundandar, "Antara Jamaah dan Partai Politik: Dinamika Habitus Kader Partai PKS dalam Arena Politik Indonesia Pasca Pemilu 2004” (Disertasi--FISIP Universitas Indonesia, 2011).

10 Zudi Setiawan, "Dinamika Pergulatan Politik dan Pemikiran Formaliasi Syariah pada Era Reformasi Spektrum", Jurnal Ilmu Politik Hubungan Internasional, Vol. 5, No. 2 (Juni 2008). 
berargumentasi bahwa hal tersebut disebabkan oleh strategi politik yang digunakan masih terjebak dalam fomalisasi agama (sharî‘ah). Apalagi, isu tersebut ternyata tidak cukup mendapat dukungan dari ormas Islam seperti Muhammadiyah dan NU. Dalam analisisnya, dia menemukan bahwa mayoritas Islam di Indonesia lebih menyukai isuisu politik yang langsung bersentuhan dengan kehidupan masyarakat sehari-hari, seperti penuntasan kemiskinan, perbaikan infrastruktur publik, dan peningkatan kelayakan hidup. ${ }^{11}$

Dari beberapa studi penting di atas, studi ini akan memberikan tiga kontribusi yakni: Pertama, menguraikan bagaimana hubungan antara pengaruh politik Timur Tengah dengan aktualisasi program partai politik Islam di Indonesia. Kedua, memperkuat analisis tentang strategi gerakan politik Islam melalui partai politik di Indonesia yang cenderung adaptatif terhadap konteks budaya politik yang sudah eksis. Ketiga, menggambarkan pola adaptasi, modifikasi dan transformasi pemikiran politik Timur Tengah ke dalam program-program partai politik.

\section{Genealogi Pemikiran Politik Partai Islam Pasca-Orde Baru}

Pemikiran politik dalam partai berbasis Islam di Indonesia tidak bisa dilepaskan dengan arus pemikiran politik Islam yang ada di Timur Tengah. Setidaknya ada beberapa alasan yang mendasari. Pertama, diskursus tentang Islam di negara-negara Timur Tengah mendapatkan perhatian yang luas baik dalam fungsi keagamaan maupun dalam bidang kehidupan lain, seperti politik, sosial, dan ekonomi. Kedua, di Timur Tengah muncul tokoh-tokoh pemikir Islam yang berpengaruh dalam dunia Islam. Hal ini bisa dilihat dari kitab-kitab yang diajarkan di pesantren atau lembaga pendidikan keagamaan di Indonesia yang membahas dan mengajarkan kitab dari intelektual Muslim Timur Tengah. Ketiga, terdapat jaringan yang kuat antara ulama Timur Tengah dan ulama Nusantara yang dimulai sejak abad 17 dan 18. Jaringan ini membuat pengembangan keilmuan yang bersumber dari Timur Tengah berjalan dengan baik di Indonesia. ${ }^{12}$ Dari jaringan keilmuan ini salah satunya berimplikasi kepada pemikiran politik di Indonesia yang dikembangkan oleh para politisi Islam di Indonesia

\footnotetext{
11 Ahmad Fuad Fanani, "Dilema partai Politik Islam: Terpuruk dalam Kegagalan atau Menjawab Tantangan?”, Jurnal Maarif, Vol. 8, No. 2 (Desember 2013).

12 Lebih lengkap bisa lihat Azyumardi Azra, Jaringan Ulama Timur Tengah dan Kepulauan Nusantra Abad XVII dan XVIII. Akar Pembaruan Islam Indonesia: Edisi Perenial (Jakarta: Kencana Prenada Media Group, 2013).
} 
sebagaimana pada era pascakemerdekaan seperti M. Natsir dan eliteelite Partai Masyumi.

Dalam melacak genealogi pemikiran politik, bisa diawali dengan melihat konsepsi politik Islam yang berkembang di Timur Tengah tentang pemikiran negara (dawlah) dan politik (siyâsah). Dalam sejarah pemikiran politik Islam memang tidak ada ketentuan khusus mengenai bentuk dan konsep negara Islam yang dikehendaki dan final. ${ }^{13}$ Oleh karena itu, selepas meninggalnya Nabi Muhammad, hal yang menjadi urusan pertama dan pelik bukanlah tentang agama, melainkan urusan politik. ${ }^{14}$ Dengan kondisi tidak adanya pakem tentang konsep negara Islam, sementara usaha penafsiran atas alQur'ân dan al-Ḥadîth dilakukan oleh intelektual Muslim untuk menginterpretasi ajaran Islam ke dalam wilayah politik. Hasilnya, perdebatan dan perbedaan di kalangan intelektual Muslim tidak bisa dihindarkan dan menjadi bagian dari khazanah keilmuan Islam.

Titik awal yang menjadi perhatian intelektual Muslim adalah kedudukan agama dan negara, dan bagaimana replikasi negara ideal sesuai dengan ajaran Islam. Jika dilihat dari arus pemikiran politik yang berkembang, terdapat tiga tipologi pemikiran. Pemikiran pertama memiliki pandangan bahwa Islam merupakan agama yang universal dan paripurna. Islam bukanlah agama sebagaimana ditafsirkan oleh Barat, yang hanya mengatur urusan yang transendental, tetapi lengkap dengan urusan keduniaan, sehingga agama dan negara harus integral, tidak boleh dipisahkan. Pemikiran yang kedua memiliki pandangan bahwa kedudukan agama dan negara merupakan sesuatu yang saling terikat tapi tidak menyatu. Islam tidak mengatur secara khusus negara yang seperti apa yang mesti dijalankan, sehingga diserahkan sepenuhnya kepada masyarakat Muslim yang ada di negara tersebut. Pemikiran yang ketiga cenderung sekularistik yang menyatakan bahwa agama dan negara terpisah. ${ }^{15}$

Di antara tokoh pendukung pemikiran agama dan negara adalah satu kesatuan adalah Hasan al-Bannâ. Pendiri IM tersebut memiliki pandangan bahwa Islam adalah sebuah sistem komprehensif yang mampu berkembang sendiri; sumber utama Islam adalah al-Qur'ân

\footnotetext{
13 Abd. Salam Arif, "Relasi Agama dan Negara dalam Perspektif Islam", Hermeneia: Jurnal Kajian Islam Interdisipliner, Vol. 2 No. 2 (Juli-Desember 2003), 279.

${ }^{14}$ Harun Nasution, Islam Ditinjau dari Berbagai Aspek (Jakarta: UI Press, 1979), 92.

${ }^{15}$ Munawir Sjadzali, Islam dan Tata Negara: Ajaran, Sejarah, dan Pemikiran (Jakarta: UI Press, 1993), 1-2.
} 
dan al-Ḥadîth; Islam berlaku untuk segala tempat. ${ }^{16}$ Menurutnya, sistem pemerintahan Islam wajib menegakkan sharî‘ah sebagai Undang-undang tertinggi negara. ${ }^{17}$ Tokoh lain yang memiliki pandangan serupa adalah Abû al-A'lâ al-Mawdûdî. Dia mengatakan bahwa kekuasaan tertinggi ditangan Allah dan menusia hanya sebagai pelaksana. Sistem politik Islam universal dan tidak mengenal batas wilayah geografis, bahasa, dan kebangsaan. ${ }^{18}$ Pemikiran al-Mawdûdî ini dikenal dengan pemikiran fundamentalis karena dia ingin mereformasi sistem sosial, sistem pemerintahan dan negara untuk kembali kepada konsep Islam secara total dan menolak konsep lain di luar Islam. Para pengikut konsep ini menganggap bahwa segala sesuatu yang bersumber dari Barat tidak sesuai dengan ajaran Islam, sehingga dalam ajaran-ajaran politik yang dikembangkan berusaha memurnikan kehidupan sosial kemasyarakatan sesuai dengan nilainilai Islam yang awal.

Pemikiran yang kedua cenderung lebih modernis, sebagaimana tampak dari pemikiran Muhammad Husayn Haykal. Dalam pemikirannya sistem pemerintahan harus menyangkut banyak hal, yaitu menyangkut gagasan sebuah pemerintahan secara utuh. Hal ini mencakup sistem ekonomi, moral, kemasyarakatan, dan sistem lainnya. ${ }^{19}$ Menurutnya, dalam Islam tidak terdapat pemerintahan yang baku, sebab dalam sejarah Islam terdapat corak pemerintahan yang dihasilkan dari berbagai faktor sosio-historis dan pengaruh dari kebudayaan berbagai bangsa. Umat Islam bebas memilih berbagai variasi sistem pemerintahan, yang terpenting pengelolaan negara diselenggarakan di atas prinsip musyawarah, keadilan, persamaan di depan hukum, dan berpegang pada tata nilai moral dan etika yang diajarkan dalam Islam untuk peradaban manusia. ${ }^{20}$

Pemikiran yang secara tegas mendukung adanya pemisahan agama dan negara salah satunya 'Alî 'Abd al-Râziq. Ulama hukum Mesir ini menulis karya berjudul al-Islâm wa Ușull al-Ḥukm untuk

\footnotetext{
16 Azyumardi Azra, Pergolakan Politik Islam dari Fundamentalisme, Modernisme, bingga Postmodernisme (Jakarta: Paramadina, 1996), 116.

${ }_{17}$ Muhammad Azhar, Filsafat Politik: Perbandingan antara Islam dan Barat (Jakarta: Raja Grafindo Persada, 1997), 124.

18 M. Syaminan, “Analisa Pemikiran Politik Islam”, Jurnal Politeia, Vol. 1, No. 1 (Januari 2009), 3.

19 Arsyad Sobi Kusuma, "Islam dan Politik Pemerintahan: Pemikiran Politik Muhammad Husein Haikal”, Analisis, Vol XIII, No. 2 (Desember 2013).

${ }^{20}$ Siti Musdah Mulia, Negara Islam (Depok: Kata Kita, 2010), 28.
} 
mengungkapkan bahwa tidak ada perintah dalam al-Qur'ân untuk mendirikan negara Islam berupa kbilâfah. Menurutnya, Nabi tidaklah mendirikan kerajaan dalam arti politik. Setelah Nabi wafat, maka tidak ada yang menggantikan kenabiannya. Jika pun ada Abû Bakr yang kemudian menggantikan Nabi, maka kepemimpinannya berbentuk baru yang bersifat profan. Abû Bakr menyebut dirinya sebagai khalifah Rasul (pengganti/wakil Rasul) hanya untuk membuat kaum Muslim taat kepadanya seperti taat kepada Rasululah. Orang-orang yang tidak menaatinya yang disebut Abû Bakr murtad seperti Mâlik b. Nuwayrah belum tentu murtad dalam arti keluar dari Islam dan kufur kepada Allah beserta Rasul-Nya. Berdasarkan hal itu semua Kekhalifahan lepas dari Islam dan tidak ada kaitan dengannya. Persoalan kenegaraan semuanya diserahkan pada akal pengalaman kemanusiaan belaka. ${ }^{21}$ Pemikiran al-Râziq ini juga untuk membantah pemikiran politik M. Rashîd Riḍâ dalam bukunya al-Khilâfah. ${ }^{22}$

Perbedaan pemikiran politik Islam di atas menunjukkan hal yang sama dengan partai-partai Islam yang ada di Indonesia. Sekalipun identitasnya sama-sama partai Islam, baik secara asas maupun konstituen partai, akan tetapi model dan pemaknaan politiknya mememiliki karakter yang berbeda diakibatkan sumber dan mazhab pemikiran politiknya yang berbeda-beda. PKS lebih dekat dengan pemikiran politik IM yang mengidealkan praktik keislaman dalam kerja-kerja politik. Itu sebabnya PKS secara tegas menyebutkan Islam sebagai asas partai dan menjadikan pemikiran politik al-Bannâ sebagai acuan dan rumusan dalam mengembangkan partai, mulai dari ideologi, konsep kaderisasi, dan pengembangan dakwah. ${ }^{23}$ Bagi PKS, politik Islam memiliki tiga tujuan utama yakni: menegakkan agama Islam, penegakan keadilan dan penegakan kesejahteran. ${ }^{24}$

Ideologi dan manhaj dakwah IM bisa dikatakan sama dengan PKS. Keduanya sama-sama menempatkan Islam sebagai ideologi sempurna yang dapat dijadikan rujukan dalam mengatur seluruh aspek kehidupan. Manhaj dakwah PKS pun sama dengan IM. PKS sama-

21 'Alî 'Abd al-Râziq, al-Islâm wa Ușûl al-Ḥ̂km (Kairo: Maṭba'at Miṣr, 1925) dalam Sukron Kamil, "Peta Pemikiran Islam Modern dan Kotemporer", Jurnal Universitas Paramadina, Vol. 3, No. 1 (September 2003), 69.

22 Abdul Latief Muchtar, Gerakan Kembali ke Islam: Warisan Terakbir A. Latief Muchtar (Bandung: Remaja Rosdakarya, 1998), 82.

${ }^{23}$ Rahmat, Ideologi Politik PKS, 97.

24 Lebih lengkapnya lihat Tim Formatur, Dakwah dan Siyasah dalam Perspektif Maqashid Syariah (Jakarta: Tadzkiroh Dewan Syari'ah Pusat PKS, 2008). 
sama memprioritaskan pendidikan individu agar menjadi pribadi Muslim (al-shakbsîyah al-Islamîyah) dan memilih dakwah yang bersifat gradual. Bagi PKS perjuangan menegakkan Islam dimulai dari individu. Jika individu telah terdidik pemahaman keislamannya maka dengan sendirinya Islam akan tegak sebagai sistem kehidupan. Upaya PKS menjadikan demokrasi sebagai sarana perjuangan dinilai sebagai sebuah strategi garaduasi penegakan Islam. ${ }^{25}$

Partai lain seperti PBB, lebih menghendaki sistem negara Indonesia sesuai dengan ajaran Islam. PBB menjadikan Islam sebagai asas partai dan ideologi partai. PBB menegaskan dalam AD/ART partai bahwa tujuan khusus didirikannya partai untuk tegaknya sharî‘ ${ }^{6}$ Islam dalam individu, masyarakat, dan negara. ${ }^{26}$ Lebih khusus lagi disebutkan dalam Tafsir Asas PBB bahwa ada beberapa hal yang harus dijalankan dan dipatuhi oleh anggota PBB. Pertama, Islam adalah sumber ajaran, motivasi, hukum, dan pandangan hidup. Oleh karena itu, setiap anggota PBB wajib mencerminkan sebagai Muslim yang taat akan ajaran Islam. Kedua, sharî‘ah Islam merupakan sumber hukum tertinggi yang prinsipnya dapat ditransformasikan menjadi hukum nasional. Ketiga, setiap anggota PBB wajib melaksanakan perintah amr ma'rûf naby munkar sesuai yang diperintahkan dalam alQur'ân. ${ }^{27}$

Ideologi Islam PBB tidak lepas dari kesejarahan berdirinya partai yang digagas oleh tokoh-tokoh Islam lintas organisasi. Salah satu organisasi Islam yang ikut terlibat dalam pendirian PBB ialah organisasi seperti Persatuan Islam (PERSIS) dan Dewan Dakwah Islamiyah Indonesia (DDII), organisasi Islam yang didirikan oleh M. Natsir pada tahun 1967 setelah Masyumi dibubarkan oleh Sukarno. Menurut Rahmad, peran DDII dan Nastir sangat besar dalam proses transimisi gerakan revivalisme Islam Timur Tengah ke Indonesia, mulai dari mengirim mahasiswa Indonesia untuk belajar di Timur Tengah, menerjemahkan kitab-kitab ulama Timur Tengah ke dalam bahasa Indonesia, hingga mendirikan lembaga bimbingan kursus bahasa Arab. ${ }^{28}$ Proses ini yang membuat perkembangan ideologi Islam

\footnotetext{
25 Ibid. Bandingkan Rahmat, Ideologi Politik PKS, 100.

26 Pasal 4 Tujuan, AD/ART PBB, Keputusan Muktamar ke-3, 2010.

27 Tafsir Asas PBB, Keputusan Muktamar ke-3, 2010.

${ }^{28}$ M. Imdadun Rahmat, Arus Baru Islam Radikal: Transmisi Gerakan Revivalisme Islam ke Indonesia (Jakarta: Penerbit Airlangga, 2005), 83.
} 
politik di Indonesia berkembang pesat, terutama sejak refomasi bergulir.

Keterlibatan langsung alumni Timur Tengah dalam pendirian PBB tidak sebesar seperti PKS yang lahir dari gerakan Tarbiyah kampus dan dipimpin langsung oleh alumni-alumni Timur Tengah. Ideologi Islam politik yang dikembangkan PBB memiliki hubungan genetik dengan pemikiran serupa di Timur Tengah dengan melacak pada organisasi-organiasi Islam yang terlibat dalam kelahiran PBB. Semisal keterlibatan Persis, di mana organisasi Islam ini menggabungkan ideide pemurnian IM dengan pemahaman teologi Islam dan praktik ritual, mirip dengan Saudi Arabia dengan Wahabismenya. ${ }^{29}$ Semangat mempurifikasi ajaran Islam inilah yang kemudian menjadi corak dari gerakan Islamisme PBB, di mana model pemikirannya mempunyai kesamaan dengan yang dikembangkan oleh al-Bannâ dan al-Mawdûdî.

Partai berbasis Islam lainnya seperti PPP, memiliki pandangan bahwa keberhasilan politik dalam Islam adalah ketika berhasil menegakkan sharî́ah Islam dalam konstitusi negara, sebab menurut PPP hanya Islam yang memberikan kepastian dan jaminan yang sempurna (kaffah) dalam mengatur kehidupan manusia, termasuk dalam bidang politik. Pascareformasi 1999, PPP bersama PBB berusaha menghidupkan kembali Piagam Jakarta dengan mengusulkan kepada Badan Pekerja (BP) MPR tahun 2000 dalam pembahasan amandemen UUD 1945, meskipun pada akhirnya usulan tersebut ditolak mayoritas anggota MPR. ${ }^{30}$ Prinsip politik PPP menolak perkembangan pemikiran politik yang bertentangan dengan ajaran Islam, sehingga dengan jelas dalam AD/ART disebutkan PPP menegasikan ateisme, komunisme, marxisme dan pendangkalan agama.

Pertautan pemikiran politik PPP bisa dibilang tidak monolitik, sebab partai ini didirikan dari fusi politik Partai Nahdlatul Ulama, Partai Muslimin Indonesia (Parmusi), Partai Syarikat Islam Indonesia (PSII), dan Partai Islam Perti. Corak pemikiran Islamisme yang berlangsung di PPP sangat dinamis dan memayungi dinamika antara pemikiran Islam konservatif, puritan, revivalis, dan modernis. Hal ini tampak dari visi dan misi politik PPP yang memasukkan kewajiban tuntunan hukum dan ajaran Islam, namun juga memasukkan nilai-nilai

${ }^{29}$ Howard Federspiel, Islam and Ideology in the Emerging Indonesian State: The Persatuan Islam (Persis) 1923 to 1957 (Leiden: Brill, 2001).

30 Setiawan, "Dinamika Pergulatan Politik", 81. 
demokrasi seperti hak asasi manusia, kebebasan individu, dan supremasi hukum.

Partai yang mempunyai akar organisasi keagamaan dan didirikan sebagai manifestasi perjuangan elite-elite NU dalam konteks demokratisasi Indonesia adalah PKB. Partai ini menampilkan kiprah politik sebagaimana model Husain Haikal yakni cenderung mengedepankan nilai-nilai Islam bisa intrusif dalam format negara yang sudah disepakati bersama. Tidak ada persoalan sepanjang negara memberikan jaminan untuk kebebasan beragama dan melaksanakan keyakinan masing-masing dan memberikan keamanan bagi warga negara. Pemikiran Islam modernis di dalam PKB sangat didominasi oleh K.H. Abdurrahman Wahid (Gus Dur), A. Mustofa Bisri, dan tokoh NU lainnya yang dikenal dengan pemikiran moderatnya. Pengurus PKB juga didominasi oleh orang-orang NU. Sekalipun demikian, asas partai tetap menggunakan Pancasila. Didalam pedoman politik PKB (mabda' siyâsî) disebutkan bahwa dalam menjalankan politik, PKB memperjuangkan nilai-nilai keislaman yang luhur lebih penting ketimbang berjuang mewujudkan negara Islam dengan penegakan sharî‘ah.

Demikian juga dengan Partai Amanat Nasional (PAN) yang didirikan oleh Amien Rais pada tanggal 23 Agusrus 1998 mengembangkan konsep politik Islam moderat. Jika PKB memiliki akar organisasi keagamaan dengan NU, PAN juga memiliki akar organisasi keagamaan dengan Muhammadiyah. Hal ini tidak bisa dilepaskan dari peran Amin Rais yang merupakan elite penting di Muhammadiyah. Sehingga wajar jika praktik politik yang dikembangkan PAN memiliki kesamaan dengan pandangan politik Muhammadiyah, seperti menjaga keutuhan NKRI, menjunjung tinggi nilai-nilai Pancasila, dan bekerja sama antarumat beragama.

Dari analisis tentang genealogi pemikiran Islam dalam partaipartai politik berbasis Islam di Indonesia, tampak bahwa unsur yang dominan adalah pemikiran politik Islam yang moderat dan adaptif terhadap situasi politik yang lebih terbuka dan penerimaan terhadap negara demokrasi. Sedangkan partai-partai yang tetap kaku dengan model konservatif dan lebih keras dalam menjalankan strategi dakwah yang mengedepankan penafsiran Islam politik yang kaku, cenderung gagal mendapatkan suara dalam pemilu. Dari sisi transformasi nilai dan kebaruan gerakan, partai seperti PKS mempunyai orientasi dan jaringan secara langsung dengan partai-partai serupa di Timur Tengah 
terutama di Turki. Hal ini memberikan pengaruh yang signifikan pada usaha untuk melakukan transformasi nilai politik Islam secara lebih konstekstual tetapi tetap mengandung ideologi politik yang kuat. Partai-partai lain seperti PAN, PKB, dan PPP kurang mempunyai jaringan transnasional sehingga nilai dan orientasi gerakan politiknya lebih akomodatif terhadap konteks nasional.

\section{Identifikasi Transformasi Pemikiran}

Partai politik berbasis Islam di Indonesia mendapatkan momentum kembali dalam panggung politik setelah sebelumnya sempat dibatasi oleh rezim Orde Baru. Tidak hanya partai politik Islam yang banyak berdiri, ormas keagamaan pun menjamur, dari yang bersifat lokal, nasional dan transnasional. Hal ini membawa konsekuensi pemikiran politik pascareformasi semakin dinamis. Isu politik keagamaan pun mendapat momentum dalam mewarnai arus politik Indonesia. PBB, PKS, PPP, PKB dan PAN memiliki akar historis yang berbeda dalam pendiriannya. Kami melakukan pelacakan dan identifikasi transformasi pemikiran melalui ideologi dan platform politik yang diperjuangkan dan penyesuaiannya dengan budaya politik dan cakupan konstituensinya.

Partai yang terlihat menonjol keterhubungannya dengan dinamika politik di Timur tengah adalah PKS. Sejak awal PKS mendeklarasikan diri sebagai partai dakwah, sebab kelahiran PKS diprakarsai oleh para alumni Timur Tengah yang mengembangkan gerakan Tarbiyah setelah kembali ke Indonesia. Di antara orang yang dianggap sebagai pelopor Gerakan Tarbiyah ini antara lain Hilmy Aminuddin, Salim Segaf alJufri, Abdullah Said Baharmus, dan Acep Abdul Syukur. ${ }^{31}$ Gerakan Tarbiyah ini semakin berkembang di Indonesia tatkala reformasi bergulir di Indonesia pada tahun 1998, dan para aktvis Tarbiyah alumni Timur Tengah ini memanfaatkan momentum kebebasan politik dengan mendirikan partai Islam. Gerakan Tarbiyah mengadopsi pemikiran Islam Ḥasan al-Bannâ yang bergerak dari pranata Islam tingkat individu, berlanjut ke keluarga, masyarakat, dan pemerintah. ${ }^{32}$ Ciri khas gerakan ini adalah membentuk kelompokkelompok (ḥalâqah-ḥalâqah) kecil yang terdiri dari lima hingga dua belas orang anggota (mutarabbi) untuk dibimbing oleh seorang ustadz

31 Salman, "The Tarbiyah Movement: Why People Join This Indonesian Contemporary Islamic Movement”, Studia Islamika, Vol. 13 No. 2 (2006), 189.

32 Ali Said Damanik, Fenomena Partai Keadilan: Transformasi 20 Tahun Gerakan Tarbiyah di Indonesia (Jakarta: Teraju, 2002), 190. 
atau pendidik (murabbî)..$^{33}$ Sumber utama kaderisasi muda PKS ialah Kesatuan Aksi Mahasiwa Muslim Indonesia (KAMMI). Organisasi mahasiswa KAMMI ini menjadi salah satu pembinaan PKS dalam merekrut dan membina kader-kader Islamis ala PKS. Selepas jadi mahasiswa, aktivis KAMMI ini banyak yang terlibat menjadi pengurus PKS, baik di tingkat pusat maupun daerah.

Anis Matta, salah satu elite PKS, menyebutkan bahwa tranformasi dari gerakan dakwah menjadi partai politik merupakan buah dari dua jenis konsekuensi yakni: konsekuensi ideologis dan konsekuensi politik. Konsekuensi ideologis lahir dari pandangan bahwa Islam mengatur kehidupan manusia secara komperehensif, termasuk di dalamnya politik. Pilihan gerakan dakwah menuju gerakan politik merupakan penyempurnaan dari kegaiatan dakwah. Sedangkan yang dimaksud konsekuensi politik lahir dari pandangan bahwa kegiatan dakwah akan berjalan dengan baik dalam sebuah negara apabila didukung oleh sistem politik yang baik, sehingga dakwah bisa berjalan baik dalam sebuah negara dan legal. ${ }^{34}$ Klaim PKS muncul sebagai partai politik adalah bagian dari misi dakwah. Sesuai dengan platform perjuangan politik dalam bidang dakwah, PKS membangun konsep dakwahnya dengan sebutan "orbit dakwah", di mana konsep ini

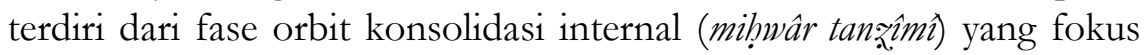
pada pembinaan kader, fase orbit masyarakat (mihwwâr al-sha'b) yang mengacu kepada pengembangan orientasi dakwah ke masyarakat lebih luas, dan fase orbit pelembagaan (mihwwâr mu'assasì) yang fokus pada proses pelembagaan dakwah dengan melakukan penetrasi ke dalam lembaga-lembaga publik untuk menerjemahkan nilai-nilai Islam ke dalam kebijakan publik, yang dikenal dengan istilah dakwah parlementer atau dakwah birokrasi. ${ }^{35}$

Keputusan PKS menjadi partai politik tidak lepas dari kepentingan untuk menjadikan demokrasi sebagai jembatan mencapai misi ideologi Islamisasi yang dicanangkan oleh PKS. Namun untuk menyesuaikan dengan sistem politik demokrasi di Indonesia, PKS melakukan penyesuaian bahkan rela bekerjasama dengan partai-partai

\footnotetext{
33 Rahmat, Ideologi Politik PKS, 12.

${ }^{34}$ Muhammad Ansor, "Asas Islam dan Artikulasi Partai Islam: Studi Perbandingan Terhadap PPP, PBB, dan PKS (1999-2004)" (Tesis-Sekolah Pascasarjana UIN Syarif Hidayatullah Jakarta, 2004).

${ }^{35}$ Majelis Pertimbangan Pusat Partai Keadilan Sejahtera, Memperjuangkan Masyarakat Madani: Edisi GabunganFalsafah Dasar Perjuangan dan Platform Kebijakan Pembangunan Partai Keadialan Sejabtera (Jakarta: Majelis Pertimbangan Pusat PKS, 2008), 50-56.
} 
di luar Islam untuk kepentingan dinamisasi partai, baik itu dalam rangka agar PKS mendapat jatah "kursi" di pemerintahan maupun untuk pencitraan PKS agar diterima masyarakat luas. Dalam strategi politiknya, PKS cenderung menyadari bahwa demokrasi yang muncul dari Barat tidak dapat sepenuhnya diadopsi dalam Islam, namun demikian harus melihat kenyataaan, apalagi di Indonesia yang plural. PKS sadar bahwa dengan demokrasi mereka diuntungkan karena bisa berpartisipasi dalam pemilu. Agar demokrasi ini bisa bermanfaat bisa diarahkan kepada kemaslahatan rakyat. ${ }^{36}$ Dari sini PKS mulai membangun legitimasi bahwa pilihan PKS mendukung demokrasi juga bagian dari untuk suksesi menegakkan nilai-nilai Islam.

Belajar dari minimnya perolehan suara Partai Keadilan (PK) pada pemilu 1999, menyebabkan perubahan orientasi gerakan dan strategi. Mereka menanggalkan citra sebagai organisasi politik garis keras dan melakukan formulasi ideologinya menjadi lebih fleksibel dan lunak untuk mendapatkan simpati dan dukungan masyarakat secara luas. ${ }^{37}$ Salah satu elite PKS yang berperan dalam proses transformasi tersebut adalah Hidayat Nur Wahid, deklarator PKS yang secara resmi menjadi Presiden PKS pada tahun 2000 menggantikan koleganya Nur Mahmudi Ismail. Nur Wahid secara terbuka menyatakan bahwa ideologi bangsa adalah Pancasila yang menghormati keberagamaan Indonesia. ${ }^{38}$ Dalam kepemimpinannya, PKS menampilkan wajah Islam modernis tanpa menghilangkan misi utamanya yang sudah menjadi ruh dan identitas PK. ${ }^{39}$ Sukses terbesar PKS dalam menciptakan citra partai Islam moderat dan mengangkat isu-isu populis, seperti kejujuran, keadilan, dan partai bersih, bebas korupsi dan kolusi membuat PKS mendulang dukungan tinggi dari masyarakat. Pada pemilu 2009, PKS mendapat suara 7,8 persen, perolehan suara paling tinggi di antara partai berbasis Islam lainnya saat itu. ${ }^{40}$

\footnotetext{
36 Sudarno Shubron, "Islam dan Demokrasi: Implementasi dalam Gerakan Islam Indonesia", Akademika: Jurnal Kebudayaan, Vol. 4, No. 1 (November 2009), 62.

37 Sunny Tanuwidjaja, "PKS in post-Reformasi Indonesia: Catching The Catch-All and Moderation Wave", South East Asia Research, Vol. 20, No. 4 (2012), 537.

38 http://jakartaglobe.beritasatu.com/news/ideology-gets-abandoned-votes/diakses pada 20 April 2016

39 Faishal Aminuddin, "Reorganisasi Partai Keadilan Sejahtera di Indonesia", Jurnal Studi Pemerintahan, Vol. 1. No. 1 (Agustus 2010), 134.

${ }^{40}$ Jan Woischnik dan Philipp Muller, "Islamic Parties and Democracy in Indonesia", Kas International Report, Oktober 2013, 63.
} 
Penyesuaian PKS dengan sistem demokrasi membuat PKS melakukan pergeseran identitas politik yang sebelumnya menjadi partai tertutup, dalam artian hanya beranggotakan Muslim berubah menjadi partai terbuka yang diputuskan dalam Musyawarah Nasional Ke-2 PKS di Jakarta pada 2010. Keputusan menjadi partai terbuka didasari atas kepentingan untuk mengakomodir pemilih PKS yang berada di daerah non-Muslim, seperti di Papua dan Nusa Tenggara Timur. ${ }^{41}$ Apabila dilihat dengan saksama, bangunan ideologi PKS yang diadopsi dari IM hanya mengambil pada konsep kaderisasi dan pembinaan kader, terutama untuk menciptakan kader yang loyal dan militan. Berkenaan dengan taktik dan strategi pencapaian misi ideologi Islam, PKS melakukan modifikasi dan kompromi dengan sistem politik Indonesia agar PKS dapat bertahan dalam sistem politik Indonesia. Ide ini salah satunya dipelopori oleh Hidayat Nur Wahid yang kemudian diteruskan oleh penggantinya.

Partai berbasis Islam lain yang lebih konservatif terlihat kurang berhasil mendulang perolehan suara dalam pemilu. PBB sejak dari awal berdirinya mengemban misi untuk menciptakan kehidupan sosial politik Indonesia sesuai dengan nilai-nilai Islam. Hal ini sangat wajar, mengingat para pendiri PBB adalah gabungan ormas Islam konservatif dan mencita-citakan tegaknya hukum Islam di Indonesia. PBB menjadikan Islam (al-Qur'ân dan al-Ḥadîth) sebagai rujukan utama dalam mengembangkan partai. Salah satu elite PBB yang memiliki peran penting dalam partai ialah Yusril Ihza Mahendra, pendiri sekaligus ketua umum partai dua periode. Yusril sejak awal sudah aktif dalam DDII dan banyak dipengaruhi oleh M. Nastir, elite penting Masyumi dan pendiri DDII. Peran Yusril sangat signifikan dalam mentransformasikan ide-ide Islam dalam PBB. Cara khas berpikir ala Masyumi ini tampak dalam pemikiran politik PBB yang cenderung anti terhadap sekularisme agama.

Pola yang digunakan oleh PKS dan PBB sangat berbeda dan membuktikan bahwa model transformasi PKS lebih sukses dalam meraih pemilih. Secara organisatoris, pengaruh dari organisasi keagamaan pendukung memang bernilai signifikan. Partai berbasis Islam lain yang mempunyai basis konstituensi dari organisasi keagamaan seperti PKB, PPP dan PAN lebih bagus dalam mendulang suara. Transformasi pemikiran Islam di PPP dapat dikatakan tidak

${ }^{41}$ Sri Herwindya Baskara Wijaya, "Komunikasi Politik Partai Terbuka ala PKS", Jurnal Komunikasi Massa, Vol. 4, No. 1 (Januari 2011), 1. 
monolitik di mana arus pemikiran Islam yang berkembang dalam PPP berdiri di atas dua fondasi, pertama Islam konservatif yang menginginkan adanya penegakan sharî‘ah Islam, yang kedua cenderung moderat dengan menerima paham-paham di luar Islam yang dianggap baik, seperti demokrasi dan kebebasan HAM. Komposisi pengurus PPP juga sangat cair dan terdiri dari berbagai golongan. Dengan bangunan dua arus ideologi tersebut, PPP dalam gerak politiknya berdiri di atas dua kepentingan. Di satu sisi mereka memperjuangkan isu-isu Islamisme atau formalisasi agama ke dalam konstitusi, seperti mendukung pengaturan hukum sharî‘ah, namun di sisi lain PPP juga memperjuangkan isu-isu politik non-Islam yang semuanya bertujuan untuk mendapatkan simpati dan dukungan dari masyarakat Islam. Model transformasi di PPP mirip dengan PKB. Perbedaannya terletak pada arus dominan Islam moderat yang lebih besar di PKB. Selain itu, $\mathrm{PKB}$ dan juga PAN memberikan ruang akomodasi dan improvisasi terhadap kader-kader politiknya untuk responsif terhadap perubahan sosial dan pemikiran yang kontekstual dengan realitas. Sekalipun kontrol kelompok konservatif masih sangat terlihat dalam elite-elite partai yang aktif di NU dan Muhammadiyah.

\section{Manifes Pemikiran Politik Islam dalam Program Kerja Partai}

Gagasan program kerja partai bisa menjadi penanda penting untuk membaca apakah program yang dicanangkan partai sudah sesuai dengan pemikiran politik Islam atau belum. Pemikiran politik ini dapat dilihat dari ideologi dan platform politik yang direalisasikan dalam program kerja partai. Peranan ideologi dalam partai sangat strategis dan sangat menentukan orientasi politik yang dicanangkan, termasuk didalamnya strategi yang digunakan untuk mencapai visi dan misi partai.

Tabel 1:

Ideologi dan platform partai berbasis Islam

\begin{tabular}{|c|c|c|c|c|}
\hline Partai & $\begin{array}{c}\text { Organisasi } \\
\text { Pendukung } \\
\text { Utama }\end{array}$ & $\begin{array}{l}\text { Dasar } \\
\text { Ideol- } \\
\text { ogi }\end{array}$ & $\begin{array}{l}\text { Nilai Dasar } \\
\text { Perjuangan } \\
\text { Partai }\end{array}$ & Platform Partai \\
\hline PPP & $\begin{array}{l}\text { Organisasi } \\
\text { Islam NU, } \\
\text { Persis, dan } \\
\text { lainnya yang } \\
\text { lebih } \\
\text { konservatif }\end{array}$ & Islam & $\begin{array}{l}\text { Ibadah } \\
\text { amr ma'rüf } \\
\text { naby munkar } \\
\text { Kebenaran, } \\
\text { Kejujuran } \\
\text { dan Keadilan }\end{array}$ & $\begin{array}{l}\text { Mewujudkan } \\
\text { kehidupan sosial politik } \\
\text { Indonesia berdasarkan } \\
\text { nilai-nilai ajaran Islam } \\
\text { Menegakkan keadilan } \\
\text { dan supremasi hukum } \\
\text { Menjaga persatuan }\end{array}$ \\
\hline
\end{tabular}




\begin{tabular}{|c|c|c|c|c|}
\hline & & & & umat Islam \\
\hline PKS & $\begin{array}{l}\text {-KAMMI } \\
\text {-Aktivis } \\
\text { Tarbiyah }\end{array}$ & Islam & $\begin{array}{l}\text { Aqidah } \\
\text { Islam } \\
\text { Keadilan } \\
\text { Kesejahteraa } \\
\mathrm{n} \\
\text { Musyawarah } \\
\text { Persatuan }\end{array}$ & $\begin{array}{l}\text { Mewujudkan } \\
\text { kehidupan politik } \\
\text { Indonesia sesuai } \\
\text { dengan ajaran Islam } \\
\text { melalui politik dakwah } \\
\text { Menegakaan keadilan } \\
\text { dan kesejahteraan bagi } \\
\text { masyarakat } \\
\text { Menciptakan budaya } \\
\text { politik yang bersih dan } \\
\text { bebas dari korupsi }\end{array}$ \\
\hline PBB & $\begin{array}{l}\text { Neo- } \\
\text { Masyumi }\end{array}$ & Islam & $\begin{array}{l}\text { Tauhid } \\
\text { amr ma'rûf } \\
\text { naby munkar } \\
\text { Keadilan } \\
\text { Persatuan } \\
\text { dan } \\
\text { Persaudaraan }\end{array}$ & $\begin{array}{l}\text { Mendorong } \\
\text { demokratisasi } \\
\text { Indonesia berdasarkan } \\
\text { prinsip ajaran Islam } \\
\text { Menegakkan sharî‘ah } \\
\text { Islam dalam setiap } \\
\text { individu, keluarga, } \\
\text { masyarakat, dan negara }\end{array}$ \\
\hline PKB & $\begin{array}{l}\text { Nahdlatul } \\
\text { Ulama }\end{array}$ & $\begin{array}{l}\text { Pancas } \\
\text { ila }\end{array}$ & $\begin{array}{l}\text { Ketauhidan } \\
\text { Keadilan } \\
\text { Kedaulatan } \\
\text { Persaudaraan } \\
\text { Moral }\end{array}$ & $\begin{array}{l}\text { Menegakkan hak asasi } \\
\text { manusia } \\
\text { Mewujudkan tatanan } \\
\text { masyarakat yang } \\
\text { sejahtera dan } \\
\text { melindungi hak-hak } \\
\text { dasar manusia, seperti } \\
\text { hak atas penghidupan } \\
\text { yang layak. }\end{array}$ \\
\hline PAN & $\begin{array}{l}\text { Muhammadi } \\
\text { yah }\end{array}$ & $\begin{array}{l}\text { Pancas } \\
\text { ila }\end{array}$ & $\begin{array}{l}\text { Kedaulatan } \\
\text { Rakyat } \\
\text { Keadilan } \\
\text { Kemajuan } \\
\text { material dan } \\
\text { spritual }\end{array}$ & $\begin{array}{l}\text { Membangun } \\
\text { masyarakat Indonesia } \\
\text { baru, berdasarkan } \\
\text { moral agama, prinsip } \\
\text { demokrasi, dan hak } \\
\text { asasi manusia } \\
\text { Mewujudkan manusia } \\
\text { Indonesia yang } \\
\text { berdaulat, memiliki jati } \\
\text { diri, cerdas, berakhlak } \\
\text { mulia, beriman dan } \\
\text { bertakwa kepada Allah, } \\
\text { Tuhan Yang Maha Esa }\end{array}$ \\
\hline
\end{tabular}

Sumber: diolah dari AD/ART Partai 
Di dalam tabel 1 terlihat bahwa partai berbasis Islam tidak lepas dari ajaran Islam sebagai sumber inspirasi pemikiran politik. Hal ini bisa dilihat dari nilai dasar perjuangan partai yang memuat nilai-nilai keislaman, seperti tauhid, amr ma'rûf naby munkar, keadilan, dan persatuan. Secara konseptual, partai Islam memaknai politik sebagai jalan ibadah, pengabdian kepada umat-jika merujuk pada gagasan partai dalam AD/ART dan nilai perjuangan partai. Partai berbasis Islam secara normatif sama-sama menghendaki adanya tatanan masyarakat yang adil, sejahtera, terpenuhi hak untuk hidup, hak berpolitik, berorganisasi, berpendapat, dan negara memberikan jaminan atas perlindungan hak-hak tersebut. Namun demikian, pemikiran masing-masing partai tidaklah sama, termasuk strategi yang digunakan oleh partai. Bagi PKS, pendekatan agama yang formal di awal kelahiran PKS sangatlah penting, namun perlahan, PKS mulai terbuka, dan pendekatan agama hanya digunakan untuk pembinaan kader dan perekrutan kader melalui pendampingan keagamaan. Hal tersebut memberikan dampak bagi program-program kerja mereka yang lebih bervariatif dan populis, mulai dari isu agama hingga isu publik yang berkaitan langsung dengan permasalahan orang banyak, seperti kemiskinan, banjir, dan lain-lain.

Pendampingan keagamaan yang dilakukan oleh PKS mengadopsi dari IM dengan model menegakkan Islam dimulai dari individu. Jika individu telah terdidik pemahaman keislamannya, menurut PKS dengan sendirinya Islam akan tegak sebagai sistem kehidupan. Tentu, pendampingan ini tidak murni berdakwah. PKS menggunakan media dakwah untuk kepentingan menarik simpati masyarakat agar dapat dipilih ketika pemilu. Target utama dari kegiatan ini adalah memberikan sugesti politik kepada masyarakat bahwa PKS adalah partai dakwah, yang siap membela kepentingan kelompok Islam. Sedangkan partai lainnya, PKB, dan PAN yang memiliki akar organisasi kegamaan dengan NU dan Muhammadiyah tetap memprioritaskan nilai-nilai keislaman terkandung dalam setiap program partai tanpa harus mengggunakan pendekatan keagamaan formal. Sesuai dengan yang tercantum dalam platform politiknya, PKB dan PAN sama-sama menyeimbangkan antara komitmen politik keislaman dengan politik kebangsaan. Sehingga program kerja partai di satu sisi menggambarkan corak pemikiran Islam, di sisi yang lain juga mengandung pemikiran kebangsaan. Begitu pula dengen PPP, namun partai ini lebih dominan pada pendekatan keagamaan formal. 
Sedangkan PBB masih menggunakan pendekataan formal keagamaan dalam setiap program kerjanya. Hal ini tidak lepas dari tujuan khusus didirikannya PBB untuk menegakkan kehidupan masyarakat sesuai dengan sharî́ah Islam, sebagaimana yang tercantum dalam platform politik. Maka tidak heran, jika program partai lebih dominan pendekatan agama. Meski harus diakui, sejak kelahiran PBB di tahun 1998, partai ini tidak dapat menyesuaikan dengan sistem dan perkembangan politik kontemporer dan menyebabkan perolehan suara PBB di setiap pemilu mengalami penurunan; pemilu 1999 mendapatkan 13 kursi, pemilu 200411 kursi dan pemilu 2009 tidak ada keterwakilan di DPR karena perolehan suara tidak mencapai parliamentary threshold.

Semua partai berbasis Islam menghendaki agar kehiudupan sosial politik di Indonesia berjalan dengan tuntunan dan ajaran Islam. Kehendak ini tercantum dalam visi dan misi partai, maupun dalam AD/ART partai. Sekalipun memiliki tujuan yang sama, antarpartai memiliki cara pandang dan format sendiri dalam mencapai tujuan tersebut. Sikap partai Islam tidak bulat dan fleksibel. Terkadang bertemu dalam satu pilihan politik yang sama, kadang pula berbeda. Selain itu, ada inkonsistensi antara pemikiran Islam yang menjadi sumber ideologi partai dengan kebijakan politik yang dikeluarkan. Dalam rangka menarik hubungan antara konsistensi antara platform partai dengan program dan advokasi mereka di parlemen, perlu dilihat melalui beberapa isu yang berhubungan langsung dengan posisi keagamaan partai-partai tersebut.

\section{Tabel II:}

Peran Partai dalam Isu Publik

\begin{tabular}{|c|c|c|c|c|}
\hline $\begin{array}{l}\text { Isu } \\
\text { Publik }\end{array}$ & Partai & Platfrom Partai & $\begin{array}{l}\text { Perjuangan } \\
\text { Parlemen }\end{array}$ & $\begin{array}{l}\text { Advokasi } \\
\text { di Publik }\end{array}$ \\
\hline \multirow{2}{*}{$\begin{array}{l}\text { Perda } \\
\text { Syraiah }\end{array}$} & PKS & $\begin{array}{l}\text { Mewujudkan } \\
\text { sistem politik } \\
\text { yang Islami. }\end{array}$ & Tidak ada & $\begin{array}{l}\text { Pendampin } \\
\text { gan } \\
\text { keagamaan } \\
\text { melalui } \\
\text { individu- } \\
\text { individu }\end{array}$ \\
\hline & PBB & $\begin{array}{l}\text {-Mendukung } \\
\text { penegakan } \\
\text { sharî́ah Islam } \\
\text { lewat individu, } \\
\text { masyarakat, dan }\end{array}$ & Belum ada & Belum ada \\
\hline
\end{tabular}




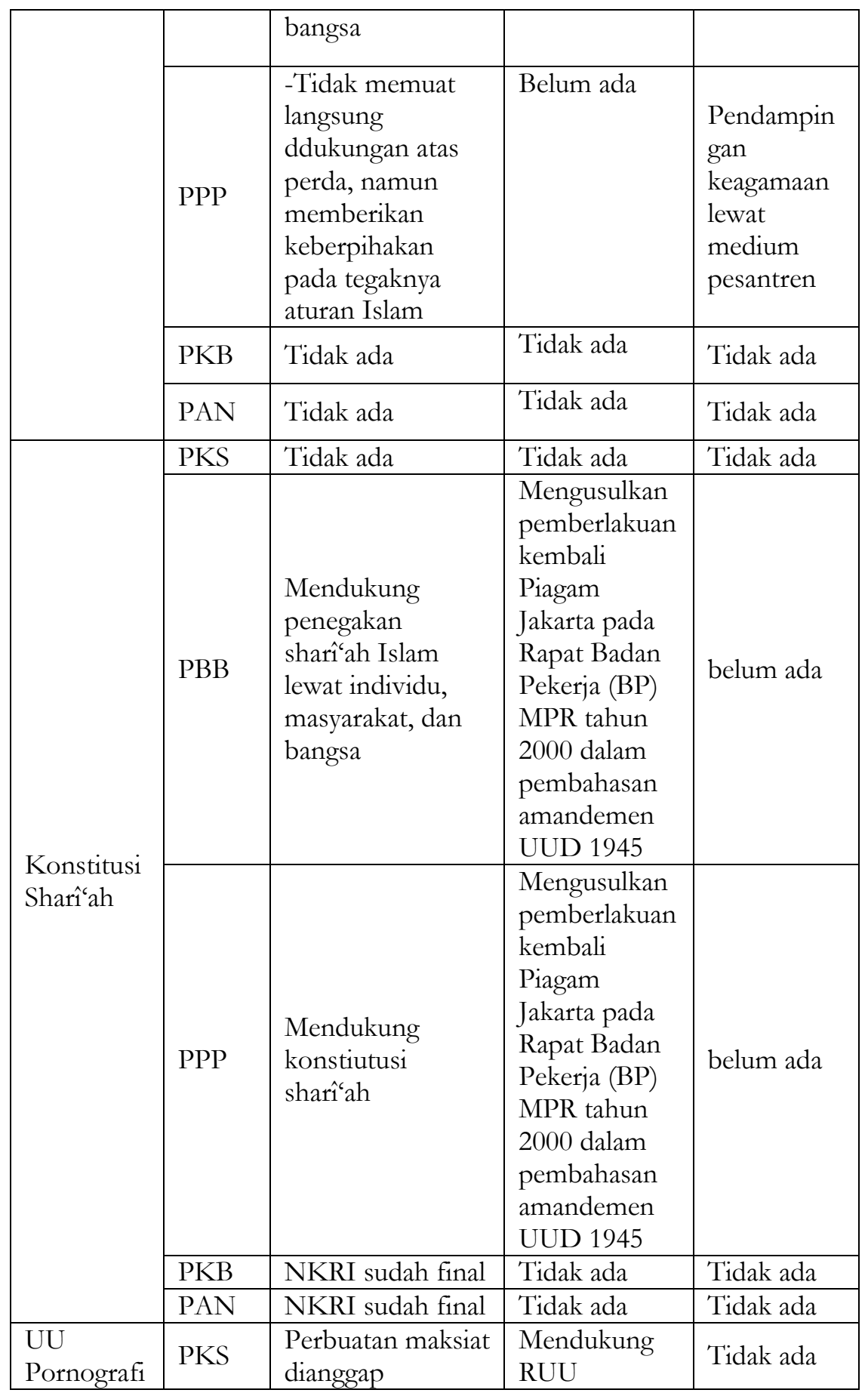




\begin{tabular}{|c|c|c|c|c|}
\hline & & $\begin{array}{l}\text { bertentangan } \\
\text { dengan Islam }\end{array}$ & $\begin{array}{l}\text { Pornografi } \\
\text { hingga } \\
\text { menjadi UU }\end{array}$ & \\
\hline & PBB & $\begin{array}{l}\text { Perbuatan maksiat } \\
\text { dianggap } \\
\text { bertentangan } \\
\text { dengan Islam }\end{array}$ & $\begin{array}{l}\text { Tidak ada } \\
\text { keterwakilan } \\
\text { di DPR }\end{array}$ & Tidak ada \\
\hline & PPP & $\begin{array}{l}\text { Perbuatan maksiat } \\
\text { dianggap } \\
\text { bertentangan } \\
\text { dengan Islam }\end{array}$ & $\begin{array}{l}\text { Mendukung } \\
\text { RUU } \\
\text { Pornografi } \\
\text { hingga } \\
\text { menjadi UU }\end{array}$ & Tidak ada \\
\hline & PKB & $\begin{array}{l}\text { Perbuatan maksiat } \\
\text { dianggap } \\
\text { bertentangan } \\
\text { dengan Islam }\end{array}$ & $\begin{array}{l}\text { Mendukung } \\
\text { RUU } \\
\text { Pornografi } \\
\text { hingga } \\
\text { menjadi UU }\end{array}$ & Tidak ada \\
\hline & PAN & $\begin{array}{l}\text { Perbuatan maksiat } \\
\text { dianggap } \\
\text { bertentangan } \\
\text { dengan Islam }\end{array}$ & $\begin{array}{l}\text { Mendukung } \\
\text { RUU } \\
\text { Pornografi } \\
\text { hingga } \\
\text { menjadi UU }\end{array}$ & Tidak ada \\
\hline \multirow{4}{*}{$\begin{array}{l}\text { RUU Anti } \\
\text { Miras }\end{array}$} & PKS & $\begin{array}{l}\text { Mendukung } \\
\text { tindakan } \\
\text { pencegahan } \\
\text { amoral }\end{array}$ & $\begin{array}{l}\text { Mendukung } \\
\text { sepenuhnya }\end{array}$ & $\begin{array}{l}\text { Sosialisasi } \\
\text { bahaya } \\
\text { miras }\end{array}$ \\
\hline & PBB & $\begin{array}{l}\text { Mendukung } \\
\text { tindakan } \\
\text { pencegahan } \\
\text { amoral }\end{array}$ & $\begin{array}{l}\text { Tidak ada } \\
\text { keterwakilan } \\
\text { di DPR }\end{array}$ & belum ada \\
\hline & PPP & $\begin{array}{l}\text { Mendukung } \\
\text { tindakan } \\
\text { pencegahan } \\
\text { amoral }\end{array}$ & $\begin{array}{l}\text { Pengusul } \\
\text { RUU Anti } \\
\text { Meras } \\
\text { (inesiator di } \\
\text { parlemen) }\end{array}$ & $\begin{array}{l}\text { Mensosialis } \\
\text { asikan } \\
\text { bahaha } \\
\text { Miras untuk } \\
\text { gnerasi } \\
\text { muda }\end{array}$ \\
\hline & PKB & $\begin{array}{l}\text { Mendukung } \\
\text { tindakan } \\
\text { pencegahan } \\
\text { amoral }\end{array}$ & $\begin{array}{l}\text { Belum } \\
\text { sepenuhnya } \\
\text { mendukung } \\
\text { karena masih } \\
\text { tumpang } \\
\text { tindih dengan } \\
\text { peraturan }\end{array}$ & - \\
\hline
\end{tabular}




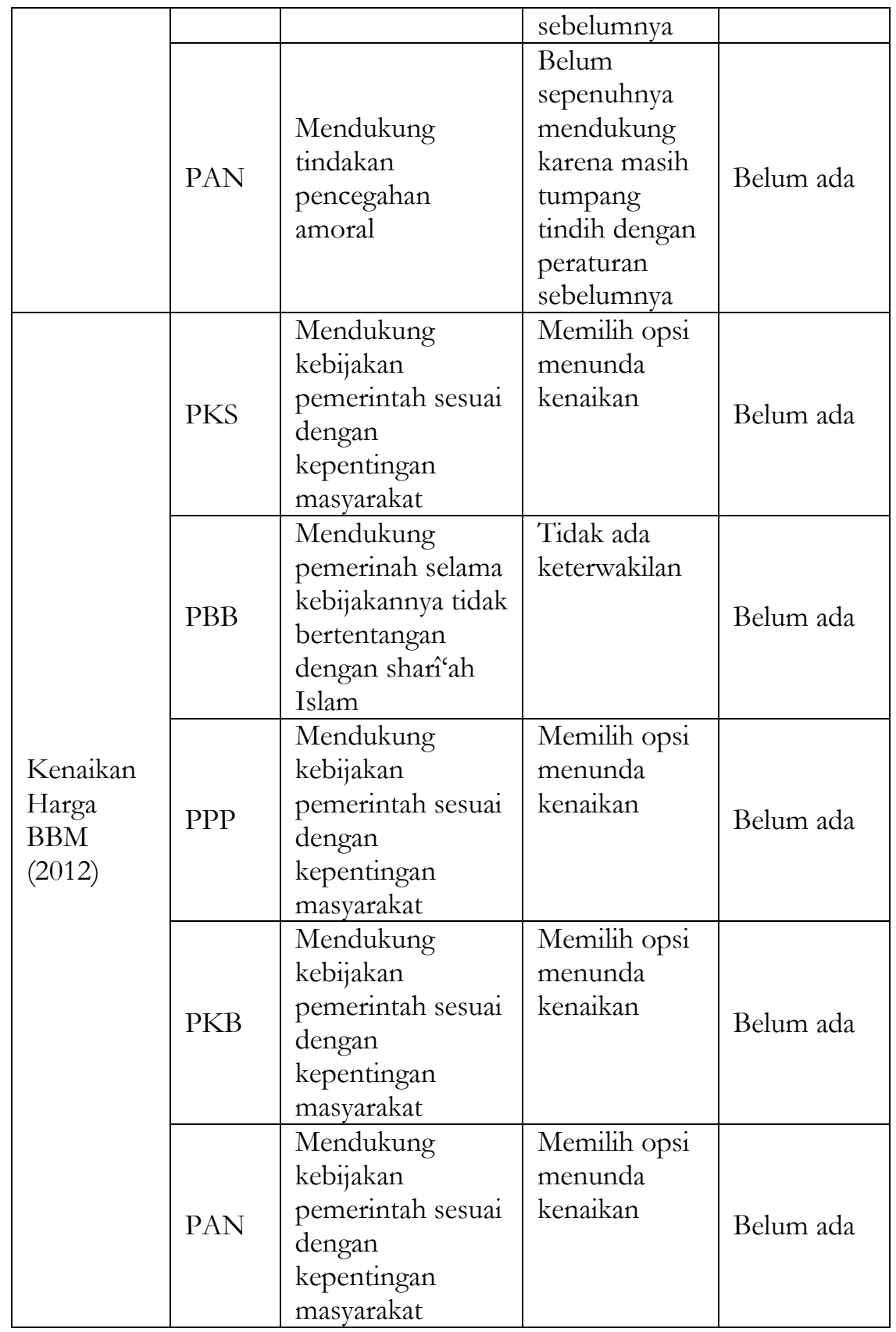

Sumber: diolah dari berbagai sumber

Tabel II di atas menunjukkan bahwa sikap partai dalam memperjuangkan isu keagamaan dan isu publik tidaklah seragam, bahkan terkadang kontras dengan identitas kepartaiannya. Misalnya 
komitmen partai berbasis Islam dalam mendukung Peraturan Daerah Syariah. Apabila dilihat dari ideologi dan platform politiknya, maka PKS, PBB, dan PPP berpotensi mendukung penerapan Perda Sharî‘ah. Namun ternyata 7 dari 33 provinsi dan 51 dari sekitar 510 kabupaten yang mengadopsi Perda Sharî‘'ah didukung oleh partai sekuler, seperti Golkar dan PDIP-kecuali di Provinsi Aceh. ${ }^{42}$ Minimnya peran partai Islam, khususnya PKS dalam mendukung Perda Sharî́ah ini tidak lepas dari strategi politik yang diperankan oleh PKS untuk menghapus citra partai Islamis garis keras agar mendapat dukungan luas dari masyarakat. ${ }^{43}$ Bahkan secara terbuka, politisi PKS menyebutkan bahwa Perda Sharî́ah tak dikenal di Indonesia, karena Indonesia bukan negara agama. ${ }^{44}$ Perjuangan formalisasi agama ke dalam konstitusi berupa aturan hukum memang tidak banyak diperankan oleh PKS, namun partai Islam lainnya seperti PPP dan PBB cenderung membuka kesempatan untuk mendukung formalisasi agama ke dalam konstitusi. Seperti dukungan fraksi PPP dan PBB untuk pemberlakuan kembali Piagam Jakarta dalam Amandemen Pasal 29 UUD 1945 tahun 2000.

Dalam menyikapi isu-isu lainnya, partai Islam memiliki pandangan yang sama, seperti pencegahan perilaku amoral berupa pornografi dan minuman keras. Fraksi PKS, PPP, dan PKB sama-sama mendukung adanya UU No. 44 Tahun 2008 Tentang Pornografi ${ }^{45}$ yang disahkan pada Rapat Paripurna DPR RI tertanggal 30 Oktober 2008. Sekalipun sejak kemunculan RUU Pornografi ${ }^{46}$ ini mengundang kritik dari berbagai pihak, terutama dari unsur aktivis gender dan kebudayaan, anggota DPR dari partai Islam tampak tak memperhitungkan

42 Michael Buehler, "Partainya Sekuler, Aturannya Syariah", TEMPO 4 September 2011.

43 Greg Fealy, "Demokrasi Mengerem Kekerasan Islam", Majalab Madina No. 4, Tahun 1 (April 2008).

44 Politisi PKS: Perda Syariah tak Dikenal di Indonesia, Republika, 10 Januari 2013.

45 RUU Pornografi sebenarnya sudah dibahas sejak tahun 1997, namun pada waktu itu penyebaran video dan gambar-gambar yang dianggap erotis masih sangat minim. RUU ini sebelumnya bernana RUU Pornografi dan Pornoaksi. Pada Rapat Paripurna Periode 1999-2004 menyebutkan RUU ini menjadi usul inisiatif pemerintah pada tanggal 23 September 2013. Kemudian pada tanggal 14 Februari 2006, draf RUU ini diajukan secara resmi dalam bentuk draft RUU. Pembahasan RUU di DPR sangat alot karena memang banyak kontroversi yang timbul, namun karena dukungan dari parlemen kuat dan desakan dari ormas Islam besar, akhirnya pada tahun 2008 RUU ini disahkan menjadi UU.

${ }^{46}$ RUU Pornografi Dinilai Cacat oleh Banyak Pihak, Kompas, 29 Septmber 2008. 
persoalan ini. RUU Pornografi sejak awal mendapat dukungaan berbagai ormasi Islam, di antaranya FPI, MUI, ICMI, MMI, dan HTI. Dukungan ormas Islam atas kebijakan politik partai Islam di pemerintahan sangat dibutuhkan, mengingat ormas Islam ini memiliki basis massa yang berguna untuk kepentingan suara ketika pemilu. Setiap keputusan yang menyangkut publik dan berkaitan dengan isu agama, partai Islam enggan berseberangan dengan ormas-ormas Islam.

Fenomena kekompakan partai-partai Islam juga tampak dalam isu Pengusulan RUU Larangan Minuman Beralkohol (Mihol) atau biasa dikenal Minuman Keras (Miras) yang diinisiasi oleh Fraksi PPP pada periode DPR RI 2009-2014 juga berangkat dari pertimbangan keagamaan. PPP menilai bahwa peredaran minuman keras sangat liar dan membahayakan terhadap generasi muda, terutama pada sisi kesehatan, mental, dan kehidupan sosial. Sekalipun dari Fraksi PPP mengatakan bahwa RUU Miras tidak bermaksud untuk menerapkan sharî‘ah Islam, namun hal itu juga menjadi bagian dari usaha untuk menerapkan sharî́ah Islam. ${ }^{47}$ Pertimbangan yang diambil oleh PPP bersumber dari ajaran Islam yang menyebutkan bahwa minuman beralkohol seperti Miras hukumnya haram untuk dikosumsi masyarakat Muslim. Alasan PPP hanyalah retoris untuk menutupi tujuan yang sesungguhnya, yakni mengatur kehidupan sosial Indonesia sesuai dengan ajaran sharî‘ ah Islam sebagaimana tercantum dalam AD/ART PPP. Meskipun hingga masa berakhirnya DPR RI Periode 2009-2015 RUU Anti Miras ini belum disahkan, namun kuatnya dukungan atas RUU Anti Miras, baik dari sesama parpol Islam maupun ormas Islam memberikan sinyal kuat bahwa misi Islamisasi tetap dilakukan oleh parpol Islam selama itu membawa dukungan kuat dari mayoritas masyarakat Muslim.

Dari beberapa kasus di atas dapat dilihat bahwa aktualisasi program partai yang diperjuangan oleh parpol Islam, baik dalam bentuk legislasi maupun non legislasi terkadang mencerminkan dari asas pemikiran Islam, sekalipun dalam implementasinya mengandung kontradiksi dengan mazhab pemikiran politik Islam yang dianut. PKS tidak akan membela Perda Sharî̀ah, meski hal itu adalah jalan menuju proses Islamisasi karena PKS dapat dianggap sebagai parpol Islam garis keras, dan ini mengancam terhadap elektabilitas PKS. Di satu

47 RUU Miras Akan Atur Peredarannya Secara Ketat, Kompas.com, 24 Desember 2012 
sisi, PKS akan membela proses Islamisasi dalam bentuk legislasi, seperti larangan pornografi dan minuman keras jika itu sejalan dengan dukungan kuat dari masyarakat, dan pola ini hampir berlaku di semua partai berbasis Islam.

\section{Penutup}

Dari pembahasan yang sudah dilakukan, studi ini menemukan bahwa dari semua partai politik berbasis Islam di Indonesia pascaOrde Baru, mempunyai penarikan yang berbeda dalam soal formalisasi ideologi politik Islam. Dari partai-partai yang menjadi objek studi ini, hanya PKS yang mempunyai jaringan transnasional yang lebih mapan dan tertata. Selebihnya, partai lain hanya melakukan adaptasi pemikiran atau gagasan politik Islam yang dikontekstualisir dengan kekuatan organisasi keagamaan pendukung di masing-masing partai. Selain itu, studi ini semakin memperjelas bagaimana proses transformasi pemikiran politik Islam terjadi dan sejauhmana adaptasi dan kompromi yang dilakukan oleh elite-elite partai untuk tetap mempertahankan identitas sebagai partai Islam disatu sisi namun melakukan penyesuaian atas posisi partai dalam isu-isu publik yang sejalan dengan kepentingan organisasi keagamaan pendukung atau konstituen nya. Dari analisis genealogis yang dilakukan, tampak bahwa pengaruh pemikiran politik Islam dari Timur Tengah terhadap partaipartai berbasis Islam tidak terjadi secara merata.

Terdapat dua hal penting yang bisa disimpulkan dari analisis tersebut. Pertama, corak politik Islam transnasional yang mulai eksis dan sukses mendapatkan dukungan politik elektoral. PKS menjadi partai yang merepresentasikan gerakan politik Islam corak tersebut dan berkembang dengan basis dukungan dan konstituensi baru. Kedua, corak politik Islam nasional yang terbagi dalam kutup konservatif dan moderat. Dalam kubu konservatif direpresentasikan oleh PPP dan PBB sementara yang moderat, banyak terlihat dari PKB dan PAN. Kesimpulan yang bisa diambil dari analisis genealogis ini memberikan pengaruh signifikan terhadap analisis yang dilakukan untuk melihat sejauhmana transformasi dan dinamika pemikiran politik Islam tersebut sampai pada tingkat perumusan dan advokasi kebijakan partai. Dalam proses ini, partai sangat tergantung pada dua tekanan yakni tekanan dari organisasi keagamaan pendukungnya dan tekanan dari koalisi partai didalam pemerintahan. Kendatipun secara umum, partai tidak mempunyai konsistensi yang cukup bagus dalam hal perumusan posisi partai yang lahir dari nilai dasar, platform dan 
program serta adovokasi yang dilakukan baik di parlemen atau di publik. Dengan demikian, secara umum bisa dihasilkan kesimpulan bahwa gerakan politik Islam dalam demokratisasi di Indonesia mengelompok menjadi dua yakni kelompok transnasionalis-adaptatif dan nasionalis-moderat.

\section{Daftar Rujukan}

\section{A. Buku dan Jurnal}

- Ideologi Politik PKS: Dari Masjid Kampus ke Gedung Parlemen. Yogyakarta: LKiS, 2008.

Aminuddin, Faishal. "Reorganisasi Partai Keadilan Sejahtera di Indonesia", Jurnal Studi Pemerintahan, Vol. 1. No. 1, Agustus 2010. an-Nabhani, Taqiyuddin. Syakhsiyah Islam, Vol. 1. Jakarta: HTI Press, 2007.

Ansor, Muhammad. "Asas Islam dan Artikulasi Partai Islam: Studi Perbandingan Terhadap PPP, PBB, dan PKS (1999-2004)". Tesis-Sekolah Pascasarjana UIN Syarif Hidayatullah Jakarta, 2004.

Arif, Abd. Salam. "Relasi Agama dan Negara dalam Perspektif Islam", Hermeneia: Jurnal Kajian Islam Interdisipliner, Vol. 2 No. 2, JuliDesember 2003.

Azhar, Muhammad. Filsafat Politik: Perbandingan antara Islam dan Barat. Jakarta: Raja Grafindo Persada, 1997.

Azra, Azyumardi. Jaringan Ulama Timur Tengah dan Kepulauan Nusantra Abad XVII dan XVIII. Akar Pembaruan Islam Indonesia: Edisi Perenial. Jakarta: Kencana Prenada Media Group, 2013.

-----. Pergolakan Politik Islam dari Fundamentalisme, Modernisme, hingga Postmodernisme. Jakarta: Paramadina, 1996.

Formatur, Tim. Dakwah dan Siyasah dalam Perspektif Maqashid Syariah. Jakarta: Tadzkiroh Dewan Syari'ah Pusat PKS, 2008.

Damanik, Ali Said. Fenomena Partai Keadilan: Transformasi 20 Tahun Gerakan Tarbiyah di Indonesia. Jakarta: Teraju, 2002.

Fanani, Ahmad Fuad. "Dilema partai Politik Islam: Terpuruk dalam Kegagalan atau Menjawab Tantangan?", Jurnal Maarif, Vol. 8, No. 2, Desember 2013.

Fealy, Greg. "Demokrasi Mengerem Kekerasan Islam", Majalah Madina No. 4, Tahun 1, April 2008.

Federspiel, Howard. Islam and Ideology in the Emerging Indonesian State: The Persatuan Islam (Persis) 1923 to 1957. Leiden: Brill, 2001. 
Kusuma, Arsyad Sobi. "Islam dan Politik Pemerintahan: Pemikiran Politik Muhammad Husein Haikal", Analisis, Vol XIII, No. 2, Desember 2013.

Muchtar, Abdul Latief. Gerakan Kembali ke Islam: Warisan Terakhir A. Latief Muchtar. Bandung: Remaja Rosdakarya, 1998.

Mufid, Ahmad Syafi'i (ed.). Perkembangan Paham Keagamaan Transnasional di Indonesia. Jakarta: Badan Litbang dan Diklat Kementerian Agama RI, 2011.

Mulia, Siti Musdah. Negara Islam. Depok: Kata Kita, 2010.

Mundandar, Arief. "Antara Jamaah dan Partai Politik: Dinamika Habitus Kader Partai PKS dalam Arena Politik Indonesia Pasca Pemilu 2004”. Disertasi--FISIP Universitas Indonesia, 2011.

Nasution, Harun. Islam Ditinjau dari Berbagai Aspek. Jakarta: UI Press, 1979.

Partai Keadilan Sejahtera, Majelis Pertimbangan Pusat. Memperjuangkan Masyarakat Madani: Edisi GabunganFalsafah Dasar Perjuangan dan Platform Kebijakan Pembangunan Partai Keadialan Sejahtera. Jakarta: Majelis Pertimbangan Pusat PKS, 2008.

Rahmat, M. Imdadun. Arus Baru Islam Radikal: Transmisi Gerakan Revivalisme Islam ke Indonesia. Jakarta: Penerbit Airlangga, 2005.

Râziq (al), 'Alî 'Abd. al-Islâm wa Ușûl al-Hukem. Kairo: Maṭba'at Miṣr, 1925.

Kamil, Sukron. "Peta Pemikiran Islam Modern dan Kotemporer", Jurnal Universitas Paramadina, Vol. 3, No. 1, September 2003.

Salman. "The Tarbiyah Movement: Why People Join This Indonesian Contemporary Islamic Movement". Studia Islamika, Vol. 13 No. 2, 2006.

Setiawan, Zudi. "Dinamika Pergulatan Politik dan Pemikiran Formaliasi Syariah pada Era Reformasi Spektrum", Jurnal Ilmu Politik Hubungan Internasional, Vol. 5, No. 2 Juni 2008.

Shubron, Sudarno. "Islam dan Demokrasi: Implementasi dalam Gerakan Islam Indonesia", Akademika: Jurnal Kebudayaan, Vol. 4, No. 1, November 2009.

Sjadzali, Munawir. Islam dan Tata Negara: Ajaran, Sejarah, dan Pemikiran. Jakarta: UI Press, 1993.

Syaminan, M. “Analisa Pemikiran Politik Islam”, Jurnal Politeia, Vol. 1, No. 1, Januari 2009. 
Tanuwidjaja, Sunny. "PKS in post-Reformasi Indonesia: Catching the Catch-All and Moderation Wave", South East Asia Research, Vol. 20, No. 4, 2012.

Widyarsa, Mohammad Riza., Fadlillah, Syafiuddin., dkk., "Pengaruh Ideologi Politik Islam di Indonesia Terhadap Partai Politik di Indonesia: Studi Kasus Partai Keadilan Sejahtera", Jurnal al-Az̧har Indonesia, Vol. 1, No. 1, Maret 2011.

Wijaya, Sri Herwindya Baskara. "Komunikasi Politik Partai Terbuka ala PKS", Jurnal Komunikasi Massa, Vol. 4, No. 1, Januari 2011.

\section{B. Surat Kabar}

Buehler, Michael. "Partainya Sekuler, Aturannya Syariah", TEMPO 4 September 2011.

Politisi PKS: Perda Syariah tak Dikenal di Indonesia, Republika, 10 Januari 2013.

RUU Miras Akan Atur Peredarannya Secara Ketat, Kompas.com, 24 Desember 2012

RUU Pornografi Dinilai Cacat oleh Banyak Pihak, Kompas, 29 Septmber 2008.

Sinyal Relasi Struktural PKS-Ikhwan, Majalah Gatra Edisi 24-30 Maret 2011. 